\title{
PENGAWASAN KOLABORATIF DALAM PELAKSANAAN KEBIJAKAN BANTUAN SOSIAL TERDAMPAK COVID-19
}

\author{
Dian Herdiana \\ Sekolah Tinggi IImu Administrasi (STIA) Cimahi \\ kyberdian@gmail.com
}

\begin{abstract}
The policy of social assistances in the framework of protecting community affected by COVID-19 empirically experienced a problem, namely data incompatabilities on Households Targets. The implication is that many residents should receive social assistances, but in fact they do not acquire them. On the other hand, those categorized as the rich instead obtain the social assistances. Based on these problems, collaborative supervision is needed to ensure that the policy runs as it should be. This article uses a qualitative approach with descriptive analysis methods, collecting data using secondary data from books, journals and website articles. The results revealed that there were no collaborative supervision efforts on the implementation of social assistance policy. The supervision process was conducted by using closed internal supervision in which other actors including the community did not have access to carry out the supervision. Thus, efforts are needed to reconstruct the supervision model of the policy implementation for social assistances that enable collaboration among stakeholders to produce an integrated and synergistic supervision system.
\end{abstract}

Keywords: Collaborative supervision, Social Assistance, COVID-19.

\begin{abstract}
Abstrak
Kebijakan bantuan sosial bagi masyarakat terdampak COVID-19 secara empiris mengalami masalah yaitu adanya kesalahan data Rumah Tangga Sasaran (RTS). Implikasinya banyak warga masyarakat yang seharusnya berhak namun tidak menerima bantuan sosial, sebaliknya warga yang mampu justru mendapatkan bantuan sosial. Didasarkan kepada permasalahan tersebut maka dibutuhkan pengawasan kolaboratif guna memastikan kebijakan tersebut berjalan sebagaimana mestinya. Artikel ini menggunakan pendekatan kualitatif dengan metode analisis deskriptif, pengumpulan data menggunakan data sekunder yaitu buku, jurnal dan laman web. Hasil penelitian menunjukan belum adanya upaya pengawasan yang dilakukan secara kolaboratif terhadap pelaksanaan kebijakan bantuan sosial dalam rangka perlindungan masyarakat terdampak COVID-19, proses pengawasan dilaksanakan dengan menggunakan model pengawasan internal secara tertutup yang mana pihak lain termasuk masyarakat tidak memiliki akses untuk melakukan pengawasan tersebut. Berdasarkan kepada hal tersebut diperlukan upaya rekonstruksi model pengawasan pelaksanaan kebijakan bantuan sosial yang memungkinkan adanya kolaborasi antar pemangku kepentingan bidang pengawasan guna menghasilkan sistem pengawasan yang integratif dan sinergis.
\end{abstract}

Kata kunci: Pengawasan Kolaboratif, Bantuan Sosial, COVID-19.

\section{PENDAHULUAN}

Corona Virus Disease 2019 (COVID-19) yang awalnya diketemukan di Kota Wuhan China pada akhir tahun 2019 menyebar dengan cepat dan menginfeksi jutaan penduduk di berbagai negara termasuk didalamnya Indonesia (World Health Organization 2020). COVID-19 telah menyebar ke hampir seluruh wilayah di 
Indonesia dan berdampak tidak hanya kepada kesehatan masyarakat, tetapi juga berdampak kepada banyak aspek kehidupan yang salah satunya kepada perekonomian masyarakat, khususnya masyarakat dari kelompok keluarga menengah ke bawah.

Dampak COVID-19 kepada perekonomian secara empiris dialami oleh seluruh lapisan masyarakat, akan tetapi keluarga dari kelompok menengah ke bawah merasakan dampak yang jauh lebih besar, mengingat sebagian besarnya merupakan para pekerja sektor informal yang banyak menggantungkan hidup kepada mata pencaharian harian. Adanya kebijakan untuk beraktivitas di rumah (stay at home) mulai dari bekerja di rumah sampai dengan belajar di rumah berakibat kepada menurunkan perekonomian sektor informal yang berimplikasi kepada menurunnya penghasilan keluarga menengah ke bawah. Adanya pemberlakuan kebijakan Pembatasan Sosial Berskala Besar (PSBB) di beberapa wilayah yang melarang aktivitas diluar pemenuhan kebutuhan pokok masyarakat untuk beroperasi berimpliksi kepada banyaknya sektor usaha mikro yang harus berhenti sementara, kondisi tersebut menyebabkan pekerja dari kelompok menengah ke bawah yang menggantungkan hidup di sektor informal tidak memiliki penghasilan, hal ini berkontribusi terhadap angka kemiskinan masyarakat yang meningkat disebabkan banyaknya keluarga dari kelompok ekonomi menengah ke bawah yang tidak dapat mencari nafkah bagi keberlangsungan hidupnya.

Kondisi tersebut direspons oleh pemerintah dengan mengeluarkan kebijakan perlindungan bagi keluarga dari kelompok menengah ke bawah yang terdampak COVID-19, baik yang berasal dari pemerintah pusat maupun yang berasal dari pemerintah daerah seperti bantuan khusus bahan pokok sembako dari pemerintah pusat untuk 2,6 juta penduduk yang ada di Provinsi Jakarta dengan besaran $\mathrm{Rp}$ 600.000 per bulan selama 3 bulan, bantuan sembako untuk wilayah Bogor, Depok, Tangerang, dan Bekasi yang diberikan kepada 1,6 juta jiwa atau 576 ribu kepala keluarga sebesar Rp 600.000 per bulan selama 3 bulan dan bantuan lainnya seperti Bantuan Langsung Tunai (BLT) dana desa yang dikhususkan bagi masyarakat yang berada di desa (Sekretariat Kabinet 2020).

Adanya kebijakan bantuan sosial yang diberikan oleh pemerintah diharapkan mampu membantu masyarakat miskin yang terdampak COVID-19 agar tetap dapat menyelenggarakan kehidupannya, akan tetapi pelaksanaan program tersebut tidak sepenuhnya berjalan sebagaimana tujuan awal yang telah ditetapkan, masalah yang muncul yaitu bahwa berbagai program tersebut tidak tepat sasaran yaitu masyarakat yang dikategorikan miskin dan berhak mendapatkan bantuan tidak mendapatkan bantuan sosial, sedangkan masyarakat yang tidak termasuk miskin dan tidak berhak mendapatkan bantuan sosial justru secara empiris mendapatkan bantuan sosial dari pemerintah (Setiawan 2020).

Bantuan sosial dalam rangka perlindungan masyarakat terdapak COVID-19 yang tidak tepat sasaran diakui oleh beberapa kepala daerah seperti oleh Gubernur Jakarta yang menyatakan bahwa terdapat $1,6 \%$ penerima bantuan sosial terdampak COVID-19 yang tidak tepat sasaran dan Gubernur Jawa Barat yang menyatakan terdapat kekeliruan dalam data Keluarga Rumah Tangga Sasaran (KRTS) dan perlu diperbaiki (Halim and Mukti 2020; Humas Provinsi Jawa Barat 2020). Pernyataan kepala daerah tersebut didukung dengan fakta empiris yang mana beberapa kepala desa menolak untuk menyalurkan bantuan sosial dikarenakan kesalahan data 
Rumah Tangga Sasaran (RTS) dikhawatirkan akan memunculkan konflik di tengah masyarakat (Ghani 2020).

Gambaran permasalahan tersebut di atas mengkonstruksikan pemahaman bahwa pelaksanaan penyaluran bantuan sosial bagi masyarakat terdampak COVID19 perlu dilakukan upaya pengawasan, hal ini didasarkan kepada beberapa alasan, yaitu: pertama, tidak tepatnya sasaran penerima bantuan sosial mengindikasikan bahwa kebijakan tersebut mengalami kegagalan sasaran kebijakan sehingga perlu upaya perbaikan, adanya proses pengawasan merupakan salah satu cara untuk memperbaiki pelaksanaan kebijakan tersebut, hal ini sejalan dengan pendapat ahli seperti Fachrudin (2004) yang menyatakan bahwa pengawasan dilakukan untuk memastikan apakah kegiatan yang dilaksanakan telah sesuai dengan tolak ukur/ kriteria-kriteria yang telah ditetapkan sebelumnya atau justru sebaliknya terdapat kesalahan atau ketidaksesuaian dalam proses pelaksanaan suatu kegiatan.

Kedua, tidak tepatnya sasaran penerima bantuan sosial mengakibatkan ketidak-harmonisan di tengah-tengah masyarakat selain memunculkan protes dan kecemburuan sosial dari masyarakat yang berhak menerima bantuan sosial tersebut, sehingga proses pengawasan dilakukan untuk memberikan rasa kepastian kepada masyarakat bahwa kebijakan bantuan sosial tersebut akan dilaksanakan sebaik mungkin, hal ini sejalan dengan pemahaman Lotulung (dalam Fachrudin 2004) yang menyatakan bahwa pengawasan dilakukan untuk menghindari terjadinya kekeliruan-kekeliruan.

Pentingnya upaya pengawasan sebagaimana dijelaskan di atas perlu dilakukan secara kolaboratif mengingat kebijakan bantuan sosial bagi masyarakat terdampak COVID-19 melibatkan aparatur pemerintah dari tingkat bawah yaitu dari tingkat desa dalam proses pendataan Rumah Tangga Sasaran (RTS) sampai dengan pemerintah di tingkat pusat mengenai jumlah anggaran pembiayaan kebijakan tersebut. Di lain sisi, kebijakan bantuan sosial bagi masyarakat terdampak COVID-19 tidak hanya diberikan oleh pemerintah pusat tetapi juga oleh pemerintah daerah, sehingga pengawasan oleh semua pihak penting dilakukan guna memastikan sinergitas dari kebijakan bantuan sosial bagi masyarakat terdampak COVID-19.

Berdasarkan kepada penjelasan tersebut di atas, maka artikel ini ditujukan untuk memberikan analisis apakah pelaksanaan bantuan sosial bagi masyarakat terdampak COVID-19 yang dilaksanakan telah diawasi secara kolaboratif dan rekomendasi model pengawasan kolaboratif seperti apa yang harus diupayakan guna mewujudkan pelaksanaan kebijakan bantuan sosial bagi masyarakat terdampak COVID-19 yang baik.

Hasil penelitian diharapkan dapat berguna sebagai bahan yang mampu menambah wawasan dan pengetahuan dalam bidang pengawasan kebijakan khususnya pengawasan kebijakan bantuan sosial, dengan begitu dapat dijadikan pertimbangan alternatif bagi para pemangku kepentingan dalam proses penyusunan kebijakan guna dapat menciptakan sistem pengawasan kolaboratif yang mampu memperbaiki pelaksanaan kebijakan bantuan sosial yang akan dilaksanakan di masa yang akan datang. 


\section{STUDI LITERATUR}

Pengawasan merunut kepada arti dalam Bahasa Indonesia diartikan sebagai penilikan atau penjagaan (Alwi 2007), pengawasan dapat disamakan juga dengan kontrol dikarenakan dalam pengembangan konsep di negara Barat istilah untuk pengawasan digunakan kata controlling (Muchsan 2007). Menurut Soekarno (1982) pengawasan merupakan bentuk penjaminan atas penetapan pekerjaan yang sudah dilaksanakan agar dapat terlaksana sesuai dengan rencana awal.

Menurut Harahap (2011) bahwa pengawasan merupakan upaya memeriksa kembali terhadap semua hal yang telah dilaksanakan sesuai dengan rencana yang telah ditetapkan, perintah yang dikeluarkan dan prinsip yang dianut guna menghindari kesalahan serupa terjadi di masa depan. Berdasarkan kepada pemahaman tersebut maka pengawasan bertujuan untuk memastikan pelaksanaan kegiatan sesuai dengan tujuan awal, hal ini sejalan dengan pemahaman Marihot (2001) yang menyatakan bahwa tujuan pengawasan yaitu untuk mengamati apa yang sebenarnya terjadi dengan apa yang seharusnya terjadi untuk kemudian menemukenali penyimpangan yang terjadi agar menjadi bahan koreksi oleh pimpinan.

Berdasarkan kepada pemahaman pengawasan merupakan proses yang menekankan kepada aktivitas yang dilakukan dalam suatu organisasi dalam relasi antara pimpinan, pegawai dan kinerja atau program kerja. Pertanyaan kemudian apakah pengawasan dapat dikaji secara lebih fokus terhadap berjalannya suatu rencana atau program, pertanyaan tersebut menurut penulis bisa dilakukan karena objek dari pengawasan tidak terbatas kepada aktivitas manusia dalam organisasi tetapi juga kepada rencana atau kegiatan yang telah ditetapkan, hal ini sejalan dengan pemahaman dari (Lotulung 1986) yang menyatakan bahwa pengawasan atau kontrol ditujukan untuk menghindari terjadinya kekeliruan, sebagai usaha preventif atau usaha represif.

Berdasarkan kepada pemahaman tersebut di atas maka segala hal yang terkait dengan proses memastikan keberfungsian kegiatan agar terlaksana sesuai dengan rencana yang telah disusun atau ditetapkan sebelumnya merupakan bagian yang dapat diawasi. Pemahaman tersebut dikaitkan dengan kajian mengenai pelaksanaan kebijakan bantuan sosial bagi masyarakat terdampak COVID-19, maka pengawasan merupakan upaya yang dilakukan untuk memastikan apakah aparatur pemerintah yang diberikan kewenangan dalam pelaksanaan kebijakan bantuan sosial tersebut dapat menjalankan perannya yang dibuktikan dengan kemauan, komitmen dan kapasitas untuk memastikan kebijakan bantuan sosial dapat terlaksana dengan baik yang salah satunya disalurkan kepada kelompok sasaran yang tepat.

Pengawasan kolaboratif merupakan bentuk pengawasan yang didasarkan adanya pergeseran adopsi nilai dari government ke governance. Merujuk kepada pemahaman dari Dwipayana dan Eko (2003) yang menyatakan bahwa dalam konsep governance posisi pemerintah bukan merupakan agen tunggal melainkan adanya pihak lain seperti unsur swasta dan masyarakat yang sama-sama memiliki hak untuk terlibat dan berpartisipasi. Berdasarkan kepada pemahaman tersebut maka menurut penulis pengawasan kolaboratif lahir didasarkan kepada realita yang mana proses pengawasan tidak lagi cukup dilakukan oleh unsur internal pemerintah melainkan perlu mengakomodasi pihak lainnya guna memastikan kegiatan atau 
program yang dilaksanakan tersebut sesuai dengan tujuan yang telah ditetapkan di awal.

Kolaborasi (collaboration) secara konseptual memiliki perbedaan sifat dan tujuan dengan coordination dan cooperation yang mana baik coordination maupun cooperation merupakan bentuk upaya keterjalinan dari organisasi yang berbeda yang bersifat statis, sedangkan collaboration merupakan upaya keterjalinan dari berbagai pihak terkait dengan memunculkan upaya konsensus (Houge dalam Sabaruddin 2015). Atas dasar pemahaman tersebut dikaitkan dengan konsep pengawasan, maka menurut penulis pengawasan kolaboratif bukan merupakan pengawasan yang dilakukan oleh beberapa organisasi secara bersamaan yang mana antar satu dan lainnya melakukan pengawasan secara mandiri, tetapi diartikan sebagai bentuk pengawasan yang didasarkan atas adanya kesepahaman dan kerjasama antar berbagai unsur yang melahirkan sinergitas pengawasan guna menghasilkan output penilaian yang koheren. Berdasarkan kepada pemahaman tersebut maka menurut penulis, unsur dari pengawasan kolaboratif terdiri dari: Pertama, kerjasama berbagai unsur/multi aktor. Kedua, dilakukan atas dasar kesepahaman bersama (mutual understanding). Ketiga, upaya keterjalinan dalam melakukan upaya pengawasan. Keempat, kesetaraan antar aktor dan sinergitas. Kelima, hasil pengawasan merupakan konsensus bersama.

\section{METODE PENELITIAN}

Penulisan artikel ini menggunakan pendekatan kualitatif dengan metode analisis deskriptif. Alasan penggunaan metode tersebut yaitu didasarkan kepada tujuan penelitian untuk menganalisis mengenai pengawasan yang dilakukan terhadap pelaksanaan penyaluran bantuan sosial bagi masyarakat terdampak COVID-19, sehingga dengan menggunakan metode analisis deskriptif akan dihasilkan suatu gambaran mengenai upaya pengawasan yang telah dilakukan. Pemahaman tersebut sejalan dengan pendapat dari Sugiyono (2010) yang menyatakan bahwa dalam penelitian kualitatif-deskriptif akan dihasilkan suatu penggambaran (deskripsi) mengenai fenomena yang tengah diteliti secara alamiah.

Pengumpulan data menggunakan studi dokumentasi yang mana digunakan data sekunder dari berbagai sumber yang relevan seperti buku, jurnal, peraturan perundang-undangan, laman web dan lainnya guna mengkonstruksikan realitas dan menunjang terhadap analisis terhadap fenomena yang tengah diteliti. Sedangkan teknik analisis data dilakukan melalui 3 (tiga) tahap yang meliputi tahap reduksi data, tahap penyajian data atau display dan penarikan kesimpulan (Creswell 2007).

\section{PEMBAHASAN}

Pembahasan dalam artikel ini dibagi kedalam 3 (tiga) sub-pembahasan yaitu: pertama, pelaksanaan kebijakan bantuan sosial dalam rangka perlindungan masyarakat terdampak COVID-19. Kedua, pengawasan terhadap bantuan sosial dalam rangka perlindungan masyarakat terdampak COVID-19. Ketiga, model pengawasan kolaboratif seperti apa yang harus diupayakan guna mewujudkan pelaksanaan kebijakan bantuan sosial bagi masyarakat yang baik. Adapun penjelasan secara rinci dapat diuraikan sebagai berikut: 


\section{Pelaksanaan Kebijakan Bantuan Sosial Bagi Masyarakat Terdampak COVID-19}

Kebijakan bantuan sosial bagi masyarakat terdampak COVID-19 merupakan respons pemerintah terhadap pandemik COVID-19 yang secara langsung berdampak kepada kehidupan masyarakat, khususnya bagi masyarakat miskin yang mana banyak dari mereka mengalami penurunan penghasilan atau bahkan kehilangan pekerjaan dikarenakan sumber aktivitas mata pencaharian dibatasi atau dilarang untuk beroperasi dengan dasar alasan untuk menekan laju penyebaran COVID-19.

Kehidupan ekonomi masyarakat yang terganggu akibat COVID-19 berimplikasi kepada jumlah keluarga miskin dan pengangguran yang mana menurut pemerintah diprediksi akan ada penambahan 3,78 juta jiwa penduduk miskin baru dan 5,2 juta jiwa penduduk yang mengalami Pemutusan Hubungan Kerja (PHK) dalam kondisi terburuk pandemik COVID-19 (Tambun 2020). Atas dasar tersebut maka sektor ekonomi masyarakat menjadi salah satu sektor yang paling terdampak dari adanya pandemik COVID-19 sehingga upaya perlindungan pemerintah terhadap ekonomi masyarakat khususnya masyarakat miskin menjadi mutlak untuk dilakukan.

Kebijakan bantuan sosial bagi masyarakat terdampak COVID-19 merupakan salah satu upaya yang ditempuh oleh pemerintah guna melindungi keluarga miskin dari adanya dampak pandemi COVID-19, bantuan sosial tersebut terdiri dari bantuan yang berasal dari pemerintah pusat dan bantuan yang berasal dari pemerintah daerah. Bantuan sosial yang berasal dari pemerintah pusat antara lain yaitu: pertama, Bantuan Khusus Bahan Pokok Sembako untuk 2,6 juta penduduk yang ada di Provinsi Jakarta dengan besaran Rp 600.000 per bulan selama 3 bulan. Kedua, Bantuan Sembako untuk wilayah Bogor, Depok, Tangerang, dan Bekasi yang diberikan kepada 1,6 juta jiwa atau 576 ribu Kepala Keluarga sebesar Rp 600.000 per bulan selama 3 bulan. Ketiga, untuk masyarakat di luar Jabodetabek, akan diberikan Bantuan Sosial Tunai kepada 9 juta Kepala Keluarga yang tidak menerima Bansos Program Keluarga Harapan maupun Bansos Sembako sebesar sebesar Rp 600.000 per bulan selama 3 bulan (Sekretariat Kabinet 2020).

Bantuan dari pemerintah daerah memiliki perbedaan antara satu wilayah dengan wilayah lainnya baik jenis bantuan maupun jumlahnya, akan tetapi samasama dikhususkan sebagai jaring sosial bagi masyarakat terdampak COVID-19, bantuan sosial tersebut semisal oleh pemerintah provinsi Jawa Barat yang memberikan bantuan pangan bagi masyarakat sasaran dan bantuan tunai senilai uang Rp 500.000 per Rumah Tangga Sasaran/RTS (Humas Setda Subang 2020).

Pemerintah provinsi Jawa Timur memberikan bantuan sosial berupa uang sebesar Rp 600 ribu per bulan selama tiga bulan bagi masyarakat miskin yang terdampak COVID-19, adapun bantuan lainnya seperti bantuan suplemen dan pelapisan Bantuan Pangan Non Tunai (BPNT), bantuan pangan tunai melalui Bantuan Keuangan Khusus (BKK), dan bantuan sosial warung sekitar pondok pesantren. Daerah-daerah lainnya baik di tingkat pemerintah provinsi maupun di tingkat pemerintah kabupaten/kota yang sama-sama wilayahnya terinfeksi COVID19 memiliki kebijakan bantuan sosial yang sama guna melindungi masyarakat yang terdampak COVID-19 (Ratya 2020). 
Adanya kebijakan sosial tersebut diharapkan beban masyarakat dalam memenuhi kebutuhan hidup sehari-hari di masa pandemi COVID-19 akan terbantu, sehingga masyarakat dapat menyelenggarakan kehidupannya dengan adanya bantuan tersebut. Menjadi permasalahan kemudian yaitu pelaksanaan kebijakan bantuan yang ditujukan bagi masyarakat miskin menjadi kontra-produktif ketika terjadi kesalahan dalam penetapan rumah tangga sasaran, masyarakat miskin yang ditargetkan dalam kebijakan bantuan sosial justru tidak mendapatkan bantuan sosial dan sebaliknya masyarakat yang dikategorikan mampu mendapatkan bantuan sosial.

Adanya salah sasaran dalam pelaksanaan kebijakan bantuan sosial dialami oleh banyak daerah, bahkan kesalahan pendataan rumah tangga yang berhak menerima bantuan sosial terjadi di Provinsi Jakarta (Dharmastuti 2020), yang mana wilayah ibukota negara dianggap sebagai wilayah yang memiliki aksesibilitas teknologi informasi dan keterjangkauan layanan administrasi pemerintahan yang lebih baik dibanding dengan wilayah lainnya. Kondisi tersebut di atas mengindikasikan bahwa adanya kesalahan penetapan Rumah Tangga Sasaran (RTS) di Provinsi Jakarta memberikan peluang yang besar akan kesalahan yang sama di provinsi lainnya, bahkan dapat diasumsikan bahwa di luar wilayah Provinsi Jakarta memiliki potensi kesalahan dalam menetapkan Rumah Tangga Sasaran (RTS) yang jauh lebih besar mengingat aksesibilitas teknologi informasi dan keterjangkauan layanan administrasi pemerintahan masih belum sebaik Provinsi Jakarta.

Pelaksanaan kebijakan bantuan sosial yang salah sasaran secara langsung memberikan dampak buruk kepada kebijakan bantuan sosial itu sendiri, mengingat tujuan perlindungan bagi masyarakat miskin yang terdampak COVID-19 menjadi tidak optimal, sebagian masyarakat miskin yang tidak menerima bantuan sosial akan tetap memiliki kesulitan dalam menyelenggarakan pemenuhan kebutuhan hidup sehari-hari. Berdasarkan kepada permasalahan tersebut maka perlu adanya upaya untuk memperbaiki kebijakan bantuan sosial khususnya dalam masalah penetapan Rumah Tangga Sasaran (RTS), sehingga kedepannya kebijakan bantuan sosial baik yang diberikan oleh pemerintah pusat maupun pemerintah daerah akan berjalan dengan optimal dan berdampak secara positif bagi rumah tangga sasaran.

\section{Pengawasan terhadap Pelaksanaan Kebijakan Bantuan Sosial bagi Masyarakat Terdampak COVID-19}

Kebijakan bantuan sosial sama dengan kebijakan lainnya yang dibuat oleh pemerintah yang harus diawasi baik secara internal maupun secara eksternal, hal ini didasarkan kepada alasan bahwa pemerintah sebagai organisasi negara yang diberikan tugas dalam penyelenggaraan pemerintahan harus dapat mempertanggungjawabkan tindakannya di depan hukum, lebih lanjut bahwa adanya pengawasan menurut Martosoewignjo (1992) merupakan salah satu unsur dari negara hukum yang mana setiap unsur dalam suatu negara tunduk dan terikat kepada hukum yang menjadi kesepakatan bersama. Berdasarkan kepada pemahaman tersebut maka kebijakan bantuan sosial merupakan produk hukum yang dibuat dan dilaksanakan oleh pemerintah sehingga harus dapat dipertanggungjawabkan di muka hukum.

Pengawasan dalam prakteknya dibagi kedalam beberapa jenis yang antara lain yaitu: Pertama, pengawasan internal yaitu bentuk pengawasan yang dilakukan 
oleh unsur atau unit dari dalam organisasi itu sendiri atau menjadi bagian dari organisasi pemerintah pada umumnya. Kedua, pengawasan eksternal yaitu bentuk pengawasan yang dilakukan oleh unsur atau unit yang berada dari luar organisasi (Brantas 2009). Lebih lanjut bahwa pengawasan dalam konteks penyelenggaraan pemerintahan yang demokratis tidak bisa melupakan peran masyarakat yang mampu memberikan input atau masukan bagi penilaian keberhasilan atau kegagalan penyelenggaraan pemerintah, pengawasan yang dilakukan oleh masyarakat dikenal juga dengan istilah pengawasan publik. Dikaitkan dengan pelaksanaan kebijakan bantuan sosial bagi masyarakat terdampak COVID-19, maka dapat diuraikan ketiga bentuk pengawasan sebagai berikut:

Pertama, pengawasan internal. Pelaksanaan kebijakan bantuan sosial bagi masyarakat terdampak COVID-19 yang tengah dilaksanakan saat ini merupakan kebijakan penyelenggaraan pemerintahan sebagai repons dari adanya pandemik COVID-19, kebijakan ini telah, tengah dan akan terus diawasi oleh unit yang ada di dalam pemerintahan, munculnya berbagai permasalahan yang salah satunya yaitu adanya ketidaksesuaian bantuan bagi Rumah Tangga Sasaran (RTS), hal ini sejalan dengan pernyataan beberapa kepala daerah yang akan memperbaiki data penerima bantuan yang sesuai dengan kondisi empiris di lapangan seperti diungkapkan oleh Gubernur Jawa Barat yang menginstruksikan jajaran di bawahnya untuk memperbaharui data masyarakat penerima bantuan yang telah ada guna disesuaikan dengan kondisi sebenarnya, hal serupa juga dilakukan oleh Gubernur Jakarta yang berkomitmen untuk meminimalisir kesalahan dalam penetapan Rumah Tangga Sasaran (RTS) dalam penyaluran bantuan sosial bagi masyarakat terdampak COVID-19 (Dharmastuti 2020; Humas Provinsi Jawa Barat 2020).

Pernyataan tersebut di atas menunjukan bahwa proses pengawasan secara internal telah berjalan, meskipun demikian proses pengawasan internal tersebut harus dilakukan terus menerus sampai dengan pelaksanaan kebijakan bantuan sosial bagi masyarakat terdampak COVID-19 selesai, sehingga akan diketahui sejauhmana pengawasan internal dilakukan guna memastikan kebijakan bantuan sosial tersebut dilaksanakan sesuai dengan maksud dan tujuan awal yang telah ditetapkan.

Kedua, pengawasan eksternal. Pelaksanaan kebijakan bantuan sosial bagi masyarakat terdampak COVID-19 yang tengah dilaksanakan diawasi pula oleh lembaga eksternal di luar pemerintahan, upaya pengawasan tersebut salah satunya dilakukan oleh Komisi Pemberantasan Korupsi (KPK) yang mana secara resmi telah mengeluarkan pernyataan akan menindak aparatur pemerintah yang terlibat dalam penyelewengan bantuan sosial bagi masyarakat terdampak COVID-19 yang mana KPK akan menuntut dengan hukuman mati apabila terbukti diketahui ada aparatur pemerintah yang korupsi terhadap dana bantuan tersebut (Prabowo 2020).

Pihak lainnya yaitu Badan Pemeriksa Keuangan (BPK) yang mana setiap penggunaan dana pemerintah akan dinilai apakah dipergunakan sesuai dengan peruntukan atau sebaliknya, upaya tersebut pada akhirnya akan menentukan apakan kebijakan bantuan sosial bagi masyarakat yang terdampak COVID-19 telah dipergunakan sesuai dengan tujuan awal kebijakan tersebut dibuat atau sebaliknya diketemukan penyimpangan-penyimpangan. Proses pengawasan dari unsur eksternal pemerintah menjadi suatu keharusan mengingat bahwa penyelenggaraan pemerintahan harus diawasi agar sesuai dengan hukum yang berlaku dan guna mewujudkan penyelenggaraan pemerintahan yang transparan dan akuntabel. 
Ketiga, pengawasan masyarakat. Masyarakat di berbagai daerah menyatakan protes terhadap pelaksanaan bantuan sosial bagi masyarakat terdampak COVID-19 yang mana dianggap tidak tepatsasatan, bentuk protes tersebut mulai dari yang diutarakan secara langsung melalui unsur perangkat desa hingga kepada tindakan mendatangi langsung kantor kecamatan (Arfah 2020; Chandra 2020). Kondisi banyaknya masyarakat yang protes terhadap pelaksanaan bantuan sosial bagi masyarakat terdampak COVID-19 mengindikasikan 2 (dua) pernyataan penting, yaitu:

Pernyataan pertama, adanya pengawasan langsung yang dilakukan masyarakat, sehingga ketika kebijakan bantuan sosial tersebut tidak sesuai dengan tujuan awal maka masyarakat menunjukan permasalahan tersebut. Dari adanya sikap masyarakat tersebut diharapkan aparatur pemerintah yang terlibat secara langsung dapat mengetahui permasalahan tersebut dan mengambil tindakan sesegera mungkin agar kesalahan dalam pelaksanaan kebijakan bantuan sosial tersebut dapat diminimalisir.

Pernyataan kedua, adanya proses pengawasan yang tidak berjalan sebagaimana mestinya yang mana masyarakat seharusnya sedari awal dilibatkan dalam proses penyusunan daftar Rumah Tangga Miskin yang dijadikan dasar dalam penetapan Rumah Tangga Sasaran (RTS), protes yang ditunjukan masyarakat menunjukan bahwa sampai dengan kebijakan bantuan sosial ditetapkan masyarakat tidak dilibatkan, sehingga ketika kebijakan tersebut dilaksanakan maka mendapat pertentangan dari masyarakat.

Permasalahan tersebut harus menjadi perhatian pemerintah agar masyarakat diberikan akses untuk terlibat dan untuk mengawasi segala bentuk penyusunan kebijakan pemerintah yang mana akan menempatkan masyarakat sebagai objek sasaran dari kebijakan tersebut, sehingga ketika kebijakan tersebut dilaksanakan masyarakat akan memiliki rasa tanggung jawab serta berpartisipasi sesuai dengan kapasitannya masing-masing.

Uraian mengenai ketiga bentuk pengawasan yang dilakukan tehadap pelaksanaan bantuan sosial bagi masyarakat terdampak COVID-19 mendorong pertanyaan apakan pengawasan yang dilakukan sudah kepada bentuk pengawasan kolaboratif?, menjawab pertanyaan tersebut, maka harus dirunut kepada unsurunsur yang harus terpenuhi dalam proses pengawasan klaboratif yang harus meliputi: Pertama, kerjasama berbagai unsur/multi aktor. Kedua, dilakukan atas dasar kesepahaman bersama/mutual understanding. Ketiga, upaya keterjalinan dalam melakukan upaya pengawasan. Keempat, kesetaraan antar aktor dan sinergitas. Kelima, hasil pengawasan merupakan konsensus bersama. Analisis terhadap pengawasan kolaboratif terhadap pelaksanaan bantuan sosial bagi masyarakat terdampak COVID-19 dapat dijelaskan sebagai berikut:

Pertama, kerjasama berbagai unsur/multi aktor. Pelaksanaan kebijakan bantuan sosial diawasi oleh berbagai unit organisasi baik secara internal maupun secara eksternal sehingga unsur multi aktor dapat dipenuhi, menjadi pertanyaan kemudian apakah adanya multi aktor tersebut memiliki keterjalinan satu dengan yang lainnya?. Secara internal fungsi unit organisasi antar pemerintah memiliki keterkaitan satu dengan yang lainnya sebagai unsur pemerintahan, akan tetapi dalam hal pengawasan maka unsur-unsur yang ada tersebut tidak memiliki keterkaitan satu dengan lainnya yang mana setiap unsur bekerja sesuai dengan tugas dan tanggungjawabnya masing-masing. Unit eksternal diluar organisasi 
melakukan pengawasan didasarkan kepada tugas dan tanggungjawabnya masingmasing, sehingga baik unsur internal maupun unsur eksternal meskipun bersifat ganda namun dalam proses pengawasannya dilakukan secara masing-masing.

Kedua, dilakukan atas dasar kesepahaman bersama/mutual understanding. Berdasarkan kepada kajian aturan bersama belum ditemukan adanya satu klausul dari peraturan perundang-undangan yang mengatur bahwa pelaksanaan pengawasan terhadap kebijakan bantuan sosial bagi masyarakat terdampak COVID19 dilakukan melalui antar lintas unit pengawas, sehingga proses pengawasan yang dilakukan berdasarkan kepada tugas dan tanggung jawab dari masing-masing unsur pemerintahan.

Ketiga, upaya keterjalinan dalam melakukan upaya pengawasan. Sebagaimana dijelaskan dalam poin ke-3 yang mana belum adanya aturan yang mengatur bentuk pengawasan bersama terhadap kebijakan bantuan sosial bagi masyarakat terdampak COVID-19, maka adanya upaya keterjalinan dalam melakukan upaya pengawasan belum dapat dilakukan sehingga tidak adanya kerjasama dalam proses pengawasan yang dilakukan secara konstruktif dan berkesinambungan antara satu unit organisasi pengawas dengan unit organisasi pengawas lainnya.

Keempat, kesetaraan antar aktor dan sinergitas. Kesetaraan aktor dalam pengawasan kebijakan bantuan sosial bagi masyarakat terdampak COVID-19 belum dapat diwujudkan mengingat belum adanya upaya yang dilakukan guna mewujudkan pengawasan secara kolaboratif. Adanya kesetaraan aktor dalam pengawasan baru akan terlihat apabila adanya aturan yang mengikat berbagai unsur pengawas untuk bersama-sama melakukan pengawasan yang menempatkan setiap unsur tersebut memiliki hak dan kewajiban yang sama.

Kelima, hasil pengawasan merupakan konsensus bersama. Pandemik COVID-19 tengah terjadi begitupun dengan kebijakan bantuan sosial bagi masyarakat terdampak COVID-19, sehingga hasil pengawasan yang dilakukan terhadap kebijakan tersebut belum bisa ditunjukan. Akan tetapi apabila diharapkan adanya bentuk laporan pengawasan bersama terhadap kebijakan bantuan sosial bagi masyarakat terdampak COVID-19 maka dapat dikatakan tidak akan diketemukan hasil pengawasan bersama mengingat tidak adanya pengawasan kolaboratif yang dilakukan.

Berdasarkan kepada uraian tersebut di atas, maka dapat dinyatakan belum adanya pengawasan kolaboratif yang tengah dilakukan oleh berbagai unsur pengawas guna memastikan pelaksanaan kebijakan bantuan sosial bagi masyarakat terdampak COVID-19 dapat berjalan sebagaimana tujuan yang telah ditetapkan di awal. Meskipun demikian upaya pengawasan kolaboratif perlu dilakukan di masa yang akan datang mengingat manfaat yang didapat dari adanya pengawasan kolaboratif sangat penting bagi terselenggaranya kebijakan bantuan sosial yang baik dan sesuai sasaran. Adapun manfaat dari adanya pengawasan kolaboratif yang akan didapat setidaknya dapat dirasakan dalam 4 (empat) aspek yang antara lain, yaitu:

Pertama, efektivitas pemanfaatan Sumber Daya Manusia (SDM). Adanya pengawasan kolaboratif memungkinkan berbagai unit organisasi pengawas bekerja sinergis secara bersamaan, kondisi tersebut akan dapat mengurangi jumlah sumber daya aparatur pemerintah yang bertugas sebagai pengawas sekaligus dapat menyeleksi aparatur yang akan menjadi pengawas sehingga diharapkan 
menciptakan aparatur pengawas yang memiliki kapasitas yang baik meskipun dalam jumlah yang relatif sedikit.

Kedua, efisiensi proses dan anggaran. Pengawasan yang dilakukan secara bersamaan akan mampu menyingkat waktu yang mana setiap unit organisasi pengawas bekerja sesuai dengan tugas dan tanggung jawabnya masing-masing, kondisi tersebut secara langsung berimplikasi kepada penghematan anggaran yang dikeluarkan sebagai biaya dari pelaksanaan kegiatan pengawasan.

Ketiga, penguatan sinergitas antar unsur organisasi pengawas. Kemampuan antar unit organisasi pengawas yang harus bekerja secara serempak antara satu sama lain akan mampu mencerminkan sinergitas dari berbagai unsur organisasi pengawas, sehingga kedepannya akan mampu menciptakan iklim kondusif bagi terselenggaranya proses pengawasan yang profesional.

Keempat, hasil laporan pengawasan yang komprehensif dan lebih kredibel. Pengawasan yang dilakukan oleh berbagai unit organisasi pengawas akan meminimalisir kesalahan yang dibuat dikarenakan satu unit organisasi pengawas dapat mengkoreksi unit organisasi pengawas lainnya, sehingga akan mampu menciptakan hasil laporan pengawasan yang selain komprehensif dikarenakan meliputi berbagai unsur yang diawasi oleh banyak unit organisasi pengawas juga menghasilkan laporan pengawasan yang jauh lebih kredibel karena sebelumnya sudah dinilai oleh internal antar unit organisasi pengawas.

Uraian mengenai pentingnya pengawasan kolaboratif sebagaimana dijelaskan di atas mengkonstruksikan pemahaman bahwa dalam terselenggaranya sistem pengawasan yang profesional perlu diupayakan sistem pengawasan yang melibatkan berbagai unsur atau unit organisasi pengawasan yang mampu bekerja secara bersinergis. Atas dasar tersebut diperlukan pula upaya yang berkelanjutan untuk membangun model pengawasan kolaboratif guna menunjang praktek pengawasan yang adaptif terhadap tuntutan jaman.

\section{Rekomendasi Model Pengawasan Kolaboratif}

Permasalahan dalam pelaksanaan kebijakan sosial baik kebijakan sosial dalam rangka penanggulangan COVID-19 maupun kebijakan sosial yang telah dilaksanakan sebelumnya dihadapkan kepada permasalahan yang sama yaitu adanya kesalahan dalam penetapan Rumah Tangga Sasaran (RTS), salah satu penyebab permasalahan tersebut yaitu tidak adanya pengawasan yang dilakukan secara optimal yang melibatkan seluruh pemangku kepentingan termasuk didalamnya melibatkan masyarakat.

Pengawasan terhadap pelaksanaan kebijakan bantuan sosial terdampak COVID-19 seperti yang tengah berlangsung saat ini secara empiris tidak dilaksanakan secara kolaboratif sebagaimana telah dijelaskan sebelumnya, kondisi tersebut mendorong pemahaman untuk membangun model pengawasan kolaboratif sebagai alternatif bagi penyelenggaraan pengawasan yang diharapkan mampu menjadi bagian dalam keberhasilan pelaksanaan kebijakan bantuan sosial pada khususnya dan kebijakan publik lainnya.

Berdasarkan kepada pemahaman tersebut, dalam artikel ini disajikan alternatif model pengawasan kolaboratif yang diharapkan dapat berkontribusi terhadap perbaikan sistem pengawasan kebijakan yang selama ini dilakukan, 
adapun pengembangan model pengawasan tersebut dapat dijelaskan melalui gambar berikut ini:

\section{Gambar 1. Model Pengawasan Kolaboratif Bantuan Sosial}

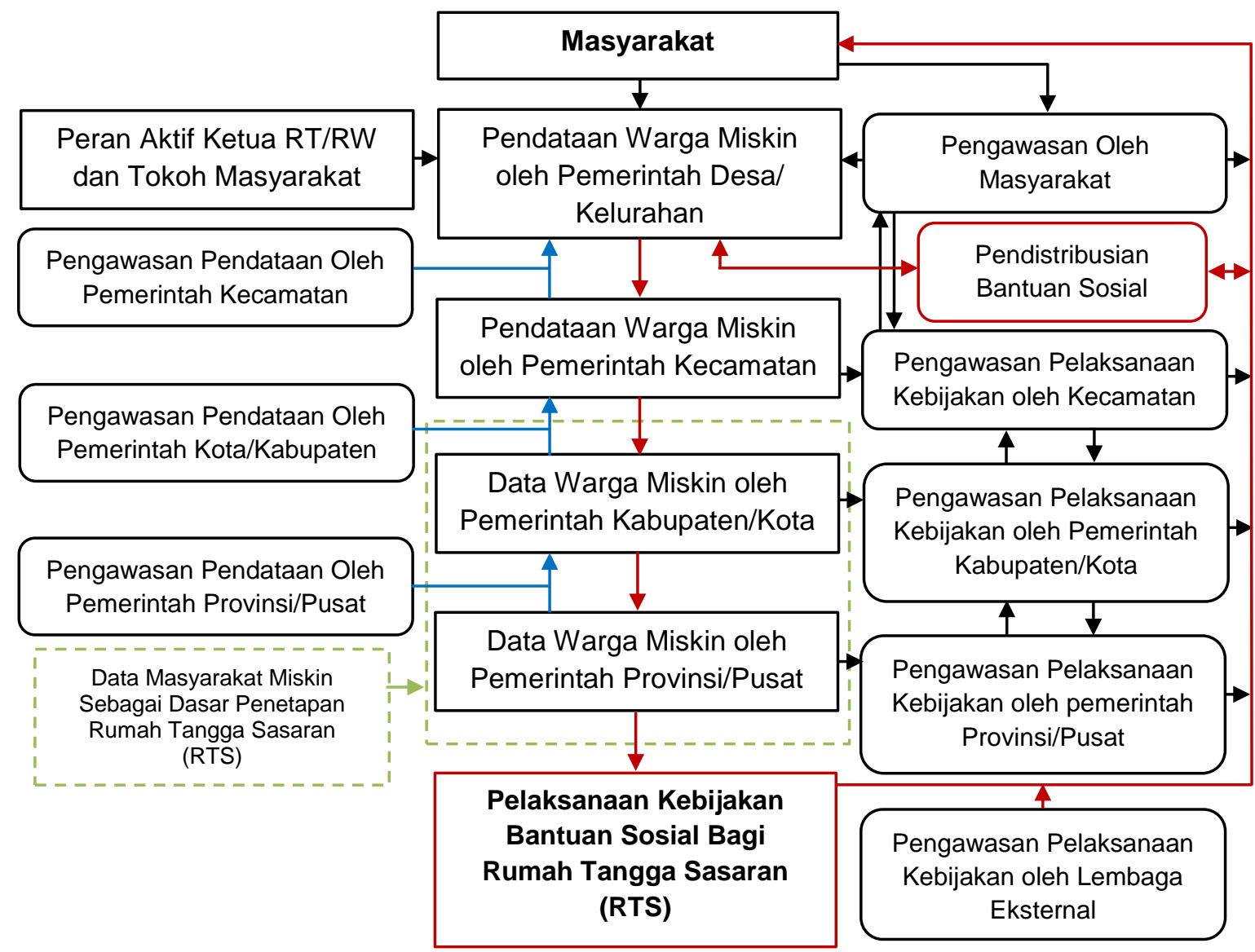

Sumber: Analisis Peneliti, 2020.

Berdasarkan Gambar 1 di atas, pelaksanaan kebijakan bantuan sosial merupakan proses berjenjang yang dimulai dari tingkat pemerintah desa atau kelurahan sampai pada tingkat pemerintah pusat dan/atau provinsi, atas dasar pemahaman tersebut maka proses pengawasan yang dilakukan harus pula dimulai secara berjenjang yang dilakukan oleh multi aktor baik secara internal di tiap-tiap level pemerintahan maupun secara eksternal, serta unsur masyarakat. Pengawasan yang dilakukan oleh para pemangku kepentingan tersebut merupakan bentuk pengawasan kolaboratif yang melibatkan berbagai unsur di setiap jenjang.

Pengawawasan kolaboratif merupakan bentuk komitmen bersama terhadap pelaksanaan kebijakan program sosial agar berjalan sebagaimana tujuan awal yang telah ditetapkan, sehingga dasar pertama adanya pengawasan kolaboroatif yaitu komitmen dan dasar aturan kerjasama dari para pemangku kepentingan untuk melakukan pengawasan secara kolaboratif. Para pemangku kepentingan tunduk dan taat kepada komitmen dan aturan yang telah dibuat dan disetujui bersama.

Proses pendataan rumah tangga sasaran (RTS) merupakan salah satu kegiatan penting yang akan turut menentukan keberhasilan pelaksanaan kebijakan 
bantuan sosial. Proses tersebut harus dilakukan secara berjenjang mulai dari unsur pemerintah desa/kelurahan yang mana pada tahap ini masyarakat turut dilibatkan baik dalam memberikan masukan terhadap penyusunan daftar rumah tangga miskin maupun mengawasi aparat pemerintah desa/kelurahan agar proses penyusunan daftar rumah tangga miskin dilakukan dengan benar.

Proses pendataan yang dilakukan secara berjenjang dan melibatkan banyak pihak mulai dari level pemerintahan terbawah sampai dengan level pemerintah pusat serta adanya pengawasan secara berjenjang diharapkan akan menghasilkan data rumah tangga miskin secara akurat dan kredibel yang menjadi dasar penetapan Rumah Tangga Sasaran (RTS) dalam pelaksanaan kebijakan bantuan sosial.

Pelaksanaan kebijakan bantuan sosial merupakan tahap yang paling penting dan krusial disebabkan dalam tahap ini keberhasilan kebijakan akan ditentukan, dalam tahap ini pula akan diketahui apakah Rumah Tangga Sasaran (RTS) yang telah disusun sesuai dengan kondisi yang sebenarnya atau sebaliknya. Didasarkan kepada pemahaman tersebut maka proses pengawasan menjadi bagian terpenting untuk memastikan bahwa kebijakan bantuan sosial terlaksana dengan baik dan Rumah Tangga Sasaran (RTS) dapat menerima manfaat dari kebijakan bantuan sosial tersebut.

Pengawasan perlu dilakukan secara multi aktor baik itu dari internal pemerintah yang terdiri dari level pemerintah pusat sampai dengan level pemerintah desa/kelurahan, serta aktor eksternal yaitu lembaga pengawas eksternal seperti Badan Pemeriksa Keuangan (BPK), lembaga non-pemerintah, maupun masyarakat baik masyarakat yang menerima manfaat maupun masyarakat luas yang memiliki perhatian terhadap keberhasilan pelaksanaan kebijakan bantuan sosial.

Upaya pengawasan kolaboratif diwujudkan dengan adanya kerjasama antar berbagai aktor di tiap level pemerintahan mulai dari tahap awal pengawasan sampai dengan tahap akhir pengawasan. Para aktor tersebut berbagi peran sesuai dengan yang telah ditentukan dan bekerja secara sinergis sehingga menghasilkan keterpaduan antara satu dengan yang lainnya.

Proses pengawasan yang dilakukan secara bersama-sama tersebut akan memunculkan dinamika dalam penilaian pelaksanaan hasil pengawasan, hal tersebut dianggap menjadi nilai positif dikarenakan adanya kekurangan dalam proses pengawasan yang dilakukan oleh salah satu pemangku kepentingan akan dikoreksi dan diperbaiki oleh pemangku kepentingan lainnya, sehingga akan menghasilkan laporan pengawasan yang komprehensif dan valid yang mana hasil tersebut merupakan kesepakatan dari para pemangku kepentingan dalam pengawasan terhadap kebijakan bantuan sosial. Hasil pengawasan akhir tersebut kemudian juga akan dijadikan sebagai bahan evaluasi dalam menentukan keberlanjutan kebijakan bantuan sosial di masa yang akan datang.

Adanya pengawasan yang dilakukan oleh para pemangku kepentingan mulai dari level pemerintah pusat sampai dengan level pemerintah desa/kelurahan diharapkan akan mengoptimalkan kinerja pelaksanaan kebijakan bantuan sosial sehingga tujuan kebijakan yang telah ditentukan di awal akan dapat tercapai dan masyarakat sasaran akan merasakan manfaat/keuntungan dari adanya kebijakan tersebut. 


\section{KESIMPULAN}

Pelaksanaan kebijakan bantuan sosial bagi masyarakat terdampak COVID-19 secara empiris menghadapi masalah khususnya kepada penyaluran yang tidak tepat sasaran, sebagian masyarakat yang termasuk kepada Rumah Tangga Sasaran (RTS) tidak menerima bantuan sosial sedangkan masyarakat yang dikelompokan mampu dan bukan merupakan Rumah Tangga Sasaran (RTS) justru menerima bantuan. Salah satu penyebab permasalahan tersebut yaitu tidak adanya pengawasan kolaboratif, proses pengawasan terhadap kebijakan bantuan sosial bagi masyarakat terdampak COVID-19 dilaksanakan dengan menggunakan pengawasan internal secara tertutup yang mana pihak lain termasuk masyarakat tidak memiliki akses untuk melakukan pengawasan tersebut.

Permasalahan dalam pengawasan pelaksanaan kebijakan bantuan sosial bagi masyarakat terdapak COVID-19 mengkonstruksikan pemahaman akan adanya urgensi rekonstruksi model pengawasan terhadap pelaksanaan kebijakan bantuan sosial didasarkan kepada 5 prinsip, yaitu: pertama, kerjasama berbagai unsur/multi aktor. Kedua, dilakukan atas dasar kesepahaman bersama (mutual understanding). Ketiga, upaya keterjalinan dalam melakukan upaya pengawasan. Keempat, kesetaraan antar aktor dan sinergitas. Kelima, hasil pengawasan merupakan konsensus bersama. Penerapan prinsip-prinsip pengawasan kolaboratif tersebut diharapkan dapat meminimalisir kesalahan dalam penetapan data Rumah Tangga Sasaran (RTS), sehingga masyarakat yang menerima bantuan sosial merupakan kelompok masyarakat yang benar dan berhak menerima bantuan sosial.

\section{REFERENSI}

Alwi, Hasan. 2007. Kamus Besar Bahasa Indonesia. Jakarta: Balai Pustaka.

Arfah, Ahmad. 2020. "Protes Tak Dapat Bansos, Warga Sunggal Deli Serdang Demo Di Kantor Camat." detik.com. https://news.detik.com/berita/d5021028/protes-tak-dapat-bansos-warga-sunggal-deli-serdang-demo-di-kantorcamat.

Brantas. 2009. Dasar-Dasar Manajemen. Jakarta: Alfabeta.

Chandra, Riki. 2020. "Bantuan Corona Tak Datang, Puluhan Warga Agam Protes." tagar.id. https://www.tagar.id/bantuan-corona-tak-datang-puluhan-warga-agamprotes (June 15, 2020).

Creswell, John W. 2007. Qualitative Inquiry and Reseach Design: Choosing Among Five Approaches. Thousand Oaks: Sage Publications.

Dharmastuti, Hestiana. 2020. "Anies Evaluasi PSBB: Akui Bansos Salah Sasaran Hingga Jakarta Belum Merdeka Corona." detik.com. https://news.detik.com/berita/d-4999308/anies-evaluasi-psbb-akui-bansossalah-sasaran-hingga-jakarta-belum-merdeka-corona (May 19, 2020).

Dwipayana, Ari AA.GN., and Sutoro Eko. 2003. Membangun Good Governance Di Desa. Yogyakarta: IRE Yogyakarta.

Fachrudin, Irfan. 2004. Pengawasan Peradilan Administrasi Terhadap Tindakan Pemerintah. Bandung: PT. Alumni Bandung.

Ghani, Halim. 2020. "Khawatir Picu Konflik, Sejumlah Kades Di Garut Enggan Salurkan BLT." detik.com. https://news.detik.com/berita-jawa-barat/d4982719/khawatir-picu-konflik-sejumlah-kades-di-garut-enggan-salurkan-blt 
(May 14, 2020).

Halim, Fikri, and Fajar Ginanjar Mukti. 2020. "Anies Benarkan Ada Salah Sasaran Dalam Penyaluran Bansos Corona." https://www.vivanews.com/berita/metro/46454-anies-benarkan-ada-salahsasaran-dalam-penyaluran-bansos-corona?medium=autonext (May 14, 2020). Harahap, Sofyan Syafri. 2011. Teori Akuntansi. Jakarta: Rajawali Press.

Humas Provinsi Jawa Barat. 2020. "Ridwan Kamil Minta Kabupaten/Kota Sempurnakan Data Penerima Bantuan." jabarprov.go.id. https://jabarprov.go.id/index.php/news/37473/2020/04/19/Ridwan-Kamil-MintaKabupatenKota-Sempurnakan-Data-Penerima-Bantuan (May 14, 2020).

Humas Setda Subang. 2020. "Penyaluran Bantuan Sosial Prov Jabar Bagi Masyarakat Terdampak Covid-19." jabarprov.go.id. https://jabarprov.go.id/index.php/news/37582/2020/04/26/Penyaluran-BantuanSosial-Prov-Jabar-Bagi-Masyarakat-Terdampak-Covid-19 (May 14, 2020).

Lotulung, Paulus Efendi. 1986. Beberapa Sistem Tentang Kontrol Segi Hukum Terhadap Pemerintah. Jakarta: PT. Buana IImu Populer.

Marihot, Manullang. 2001. Manajemen Sumber Daya Manusia. Yogyakarta: BPFE.

Martosoewignjo, Sri Soemantri. 1992. Bunga Rampai Hukum Tata Negara Indonesia. Bandung: Alumni.

Muchsan. 2007. Sistem Pengawasan Terhadap Perbuatan Aparat Pemerintah Dan Peradilan Tata Usaha Negara Di Indonesia. Yogyakarta: Liberty.

Prabowo, Haris. 2020. "Ketua KPK Ancam Hukum Mati Pelaku Korupsi Dana Bencana Corona." tirto.id. https://tirto.id/ketua-kpk-ancam-hukum-mati-pelakukorupsi-dana-bencana-corona-feRL (June 3, 2020).

Ratya, Mega Putra. 2020. "Dana Bansos Untuk Warga Terdampak Corona Di Jatim Mulai Dicairkan." detik.com. https://news.detik.com/berita/d-5005366/danabansos-untuk-warga-terdampak-corona-di-jatim-mulai-dicairkan (June 8, 2020).

Sabaruddin, Abdul. 2015. Manajemen Kolaborasi Dalam Pelayanan Publik: Teori, Konsep Dan Aplikasinya. Yogyakarta: Graha IImu.

Sekretariat Kabinet. 2020. "Pemerintah Berikan 6 Program Bantuan Tambahan Hadapi Pandemi Covid-19." Sekretariat Kabinet. https://setkab.go.id/pemerintah-berikan-6-program-bantuan-tambahan-hadapipandemi-covid-19/ (May 14, 2020).

Setiawan, Verda Nano. 2020. "Bansos Dampak Corona Tak Tepat Sasaran, Citra Pemerintah Dinilai Turun." katadata.co.id. https://katadata.co.id/berita/2020/04/26/bansos-dampak-corona-tak-tepatsasaran-citra-pemerintah-dinilai-turun (May 14, 2020).

Soekarno, K. 1982. Dasar-Dasar Manajemen. Jakarta: Miswar.

Sugiyono. 2010. Metode Penelitian Kuantitatif, Kualitatif \& Reseach and Development. Bandung: Alfabeta.

Tambun, Lenny Tristia. 2020. "Jutaan Orang Berpotensi Menganggur Dan Jatuh Miskin Akibat Covid-19." beritasatu.com. https://www.beritasatu.com/ekonomi/620653-jutaan-orang-berpotensimenganggur-dan-jatuh-miskin-akibat-covid19 (May 19, 2020).

World Health Organization. 2020. Report of the WHO-China Joint Mission on Coronavirus Disease 2019 (COVID-19). Geneva. 